WARSZTATY Z GEOGRAFII TURYZMU

ISBN 978-83-7525-713-7 $\quad$ s. 9-19

http://dx.doi.org/10.18778/7525-713-7.02

Agnieszka NIEZGODA

Uniwersytet Ekonomiczny w Poznaniu

\title{
MODA NA ZACHOWANIA PROEKOLOGICZNE W TURYSTYCE - UWARUNKOWANIA I PROBLEMY
}

\section{Wstęp}

Wybór miejsca docelowego podróży przez turystę uwarunkowany jest $\mathrm{w}$ wielu przypadkach atrakcyjnością środowiska przyrodniczego. $\mathrm{O}$ atrakcyjności tej decyduje fakt, że walory przyrodnicze są nieskażone, co uzasadnia konieczność dbałości i ochrony tych walorów. Środowisko przyrodnicze obszaru recepcji turystycznej odbiera negatywne skutki napływu turystów, dlatego niezwykle ważna staje się problematyka świadomości ekologicznej i zachowań z nią związanych, zarówno podmiotów kształtujących produkt turystyczny, jak też odbiorców tego produktu, czyli turystów.

Zachowanie turystów $\mathrm{w}$ procesie wyboru miejsca wypoczynku, a następnie wyboru poszczególnych usług i dóbr, z których turysta korzysta w tym miejscu, można zakwalifikować do kategorii zachowań konsumenckich. Zachowanie konsumentów jest częścią szerszej problematyki dotyczącej zachowania człowieka w ogóle. Problematyka ta obejmuje pytanie, dlaczego dwie osoby znajdujące się dokładnie w tej samej sytuacji mogą zachować się inaczej, bądź też zachowują się tak samo, mimo iż znajdują się $\mathrm{w}$ zupełnie różnych sytuacjach. $\mathrm{W}$ szerokim znaczeniu przez zachowanie 
rozumie się każdą reakcję na bodźce otoczenia lub ogół reakcji i ustosunkowań organizmu żywego do środowiska (RUDNICKI 2010, s. 7).

Dobra i usługi turystyczne należą do tzw. dóbr wyższego rzędu, a więc nabywane sa po zaspokojeniu potrzeb podstawowych. Powoduje to, że na procesy związane $z$ zachowaniem turystów wpływają nie tylko czynniki zewnętrzne o charakterze ogólnym (demograficzne i ekonomiczne), ale również czynniki społeczne i psychologiczne, które mają $\mathrm{w}$ wielu przypadkach decydujący wpływ na ostateczny schemat zachowań.

Można zastanowić się zatem, jakie uwarunkowania decydują o proekologicznym zachowaniu turystów. Jednym z tych uwarunkowań jest moda. Celem autorki artykułu jest analiza wpływu zjawiska mody na działania proekologiczne turystów.

\section{Moda - definicja i istota pojęcia}

W wąskim znaczeniu pojęcie mody rozumiane jest jako: „styl ubierania się charakterystyczny dla danej epoki i danego terytorium, zespół norm dotyczący zewnętrznego wyglądu człowieka, panujący przez pewien czas" (Słownik jezyka polskiego 1978). Jednak badacze zjawisk społecznych związanych z modą zauważają że jest to zjawisko społeczne obejmujące różne dziedziny życia, można nawet je określić jako zjawisko interdyscyplinarne (KÖNIG 1979, s. 7). Szersza definicja określa modę jako: „ogół przyjętych w danym odcinku czasu postaw i obyczajów obowiązujących w określonej społeczności" (SILLAMY 1994, s. 158). Jak podaje KÖNIG (1979), to uwarunkowania psychospołeczne stoją u początków modnych zachowań, by przejść potem w dziedzinę stroju, a następnie do dalszych procesów gospodarczych i kulturowych. Pełniąc różne funkcje społeczne moda powoduje konsekwencje nie tylko w zachowaniu pojedynczych osób, ale całych grup społecznych. Moda zajmuje własne miejsce w całokształcie normowanych społecznych sposobów zachowania, czym też tłumaczy się żywiołowa niekiedy siła, z jaką łamie wszelkie przeszkody. Modę w szerokim ujęciu rozumie się również jako określony sposób postępowania w różnorodnych sytuacjach i w obliczu rozmaitych przedmiotów.

W tym miejscu można przyjąć, że wyjazdy turystyczne, które upowszechniały się jako zachowanie różnych warstw społecznych były efektem mody. Początkowo była to moda na "grand tour" wśród synów bogatej arystokracji w XVIII w., potem były to wyjazdy zgodne $\mathrm{z}$ duchem romantyz- 
mu i wyjazdy „do wód” w celu kuracji bardziej lub mniej realnych chorób (w XIX w. panowała moda na to, aby szlachetnie urodzona panna była słabego zdrowia). Rozwój popularności wyjazdów o charakterze turystycznym, zapoczątkowany przez wycieczkę zorganizowaną przez Thomasa Cooka, zauważalny jest w szczególności po I, a potem po II wojnie światowej. Obecnie w krajach rozwiniętych można zauważyć pewien rodzaj presji, aby podróżować. Mogą to być podróże wynikające z większej, ogólnie rozumianej mobilności $\mathrm{w}$ życiu (zmiana miejsca pracy i miejsca zamieszkania), ale mogą to być również wyjazdy turystyczne. Co więcej, ktoś, kto nie lubi podróżować, uważany może być za dziwaka. Obserwując społeczeństwo wydaje się bowiem, że ludzie powinni chcieć się przemieszczać. W takim ujęciu można zauważyć, że wyjazdy w celach turystycznych mogą być uznane za pewną modę. Odnosząc się do teorii ról społecznych warto podkreślić, że ludzie odgrywają ich wiele, toteż zmieniają swoje decyzje związane $\mathrm{z}$ nabywaniem dóbr i usług w zależności od roli, jaką odgrywają $w$ danym momencie. $Z$ tego względu jedną $z$ głównych przesłanek współczesnego spojrzenia na badanie zachowań konsumentów jest zwrócenie uwagi, że ludzie kupują produkty nie dlatego, że do czegoś służą ale dlatego że coś symbolizują. Wyjazd turystyczny może służyć nie tylko celowi związanemu z tradycyjnie rozumianymi funkcjami turystyki (funkcja wypoczynkowa, zdrowotna, edukacyjna, poznawcza), ale może służyć pokazaniu statusu materialnego lub, po prostu, wskazaniu przynależności do określonej grupy odniesienia (postawa typu „niech inni zobaczą, że mnie również stać na taki wyjazd” lub „nie lubię jeździć na nartach, ale wszyscy przełożeni w firmie jeżdża, więc nie mogę być gorszy"). Można zauważyć, że wysokogórski krajobraz nie podlega zmianom mody, ale człowiek chodzący po górach już tym zmianom ulega.

Analizując postępowanie turystów można przytoczyć typologię SEATONA (2002), która uwzględnia perspektywę czasu oraz uwarunkowania społeczne:

a) metempsychotic - turysta prezentuje zachowania nieliniowe, wyraża siebie w czasie podróży jako wyraźnie sprecyzowaną osobę, wciąż taką sama;

b) metensomatosic - w czasie jednej podróży turysta odgrywa wiele różnych ról (zachowanie kameleona).

Według Seatona model ten pozwala na uwypuklenie poszczególnych etapów w procesie motywacji poprzez uwzględnienie dynamiki zmian w zachowaniach turystów. Ludzie stają się turystami nie poprzez dążenie do zaspokojenia własnych potrzeb, ale poprzez uwarunkowane społecznie dążenie do osobistego rozwoju. Rozwój ten odbywa się dzięki odgrywaniu 
różnych kulturowo zaaprobowanych ról społecznych. Zatem powinno się ludzi pytać nie o to "dokąd chcą jechać?”, ale „kim chcą być podczas podróży?” (szerzej: NIEZGODA 2010a).

W kontekście zachowań konsumenckich podkreślić należy, że model Seatona nie oznacza, że funkcja użytkowa produktu (usług, pakietów turystycznych) jest mało ważna, ale że role, jakie odgrywają produkty w wyborach konsumentów rozciągają się poza pełnione funkcje użytkowe. W literaturze przedmiotu zwraca się zatem uwagę na występowanie różnych relacji między nabywcą a produktem (FOURNIER 1998):

- przywiązanie do własnego ja (produkty pomagają określić tożsamość konsumenta); przykładem może być wyjazd na narty do znanego alpejskiego kurortu, aby pokazać, że jest się aktywnym, nowoczesnym i światowym;

- przywiązanie nostalgiczne (produkty pozwalają na odwołanie się do dawnego wizerunku własnej osoby); przykładem może być wyjazd starszej pani do kurortu na Riwierze w ślad za wspomnieniami dawnych wyjazdów połączonych z sukcesami towarzyskimi;

- współzależność (produkt jest odniesieniem do codziennego życia użytkownika); przykładem mogą być regularne, weekendowe wyjazdy w celu uprawiania turystyki aktywnej, bez których turysta może czuć się niekomfortowo;

- zamiłowanie (produkty wywołują silne emocje, konsument jest do nich przywiązany); mogą to być wyjazdy niezwykłe, podróże egzotyczne wspominane przez turystę przez długie lata, bądź powtarzane wyjazdy do ulubionego miejsca, które kojarzy się turyście z gwarancją określonych wrażeń i odczuć.

Wszelkie wymienione relacje też moga podlegać wpływowi mody na określone zachowania.

Analizując zjawisko mody KÖNIG (1979) wymienia dwie charakterystyczne tendencje:

1) dążenie do raptownej zmiany;

2) nagłą skłonność do bezwładu rozumianego jako wezwanie do przystosowania.

Cechą mody wynikającej z pierwszej wymienionej tendencji jest gwałtowna zmienność zachowań i gotowość do zmiany. Ludzie uważaja iż ze względu na swoją pozycję społeczną są zobowiązani iść za każdą najdrobniejszą zmianą i że to właśnie określa ich przynależność do danej grupy. Podobnie jak obyczaj moda opiera się na naśladownictwie (SILLAMY 1994, s. 158). Teoria naśladownictwa tłumaczy, w jaki sposób ludzie stojący niżej dzięki współzawodnictwu zmniejszają dystans do stojących wyżej w hie- 
rarchii (KÖNIG 1979, s. 142). Jednakże, w przeciwieństwie do naśladownictwa, odnoszącego się do zachowań utrwalonych w przeszłości, moda odnosi się do wzorców wykreowanych w teraźniejszości. W tym ujęciu moda zaspokaja potrzebę bycia oryginalnym (SILLAMY 1994, s. 158).

Druga charakterystyczna dla mody tendencja związana ze skłonnością do bezwładu wynika z procesu upodabniania zachowań. Moda daje poczucie bezpieczeństwa, albowiem stosując się do jej wymogów człowiek jednocześnie wyróżnia się jako jednostka i zyskuje akceptację swojej grupy społecznej, do której się dostosowuje. Należy jednak pamiętać, że tendencja do „bezwładu” powoduje, iż to, co było modne, w krótkim czasie zaczyna być powszechne. Moda na wyjazdy turystyczne nie dotyczy już uprzywilejowanych warstw społecznych, ale szerokich mas.

\section{Moda a zachowania proekologiczne}

Moda wywiera wpływ na postawy ludzi i ingeruje w różne dziedziny życia człowieka, dotyczy sposobu postępowania, myśli i zainteresowań konkretnej osoby. Tak jak stwierdzono powyżej, może dotyczyć wyjazdów turystycznych w ogóle, ale też szczegółowych zachowań w czasie wyjazdu. Do takich zachowań należą zachowania proekologiczne w czasie wyjazdu turystycznego. Zgodnie $\mathrm{z}$ teorią zachowań konsumenckich są to zachowania w czasie konsumpcji. Na zachowania te wpływają następujące uwarunkowania:

- wzrost zainteresowania konsumpcją, która przynosi danej osobie jak najwięcej korzyści (zdrowie, niższe rachunki itd.),

- wzrost poczucia odpowiedzialności za środowisko przyrodnicze wynikający ze świadomości ekologicznej.

Problematyka świadomości ekologicznej budzi coraz większe zainteresowanie. Przyczyn tego faktu należy szukać zarówno w rozwoju wiedzy na temat zagrożeń ekologicznych, jak też $\mathrm{w}$ poszerzeniu realnych działań na rzecz ochrony przyrody. W efekcie zauważyć można upowszechnienie tematyki świadomości ekologicznej w polityce lokalnej, krajowej i globalnej. Za moment przełomowy w kształtowaniu świadomości ekologicznej uznawany jest czas opublikowania Raportu U. Thanta "Człowiek i jego środowisko" w 1969 r. (BOHDANOWICZ 2008, s. 67). Raport ten uświadomił społeczności międzynarodowej ograniczoność zasobów naturalnych, postępującą degradację środowiska Ziemi oraz istnienie barier rozwoju gospodarczego na świecie. 
Ważnym argumentem podkreślającym konieczność badań nad świadomością ekologiczną jest dyskusja w środkach masowego przekazu nad przyczynami zagrożeń ekologicznych oraz sposobami ich przezwyciężenia. Niestety, informacje przekazywane społeczeństwu są albo bardzo specjalistyczne, albo wykorzystują lęki i stereotypy. Świadomość społeczeństwa może się zmieniać wraz z szeroko rozumianym zwrotem kulturowym. Ekolodzy uważaja, że: „kulturę ekspansji i filozofię rozwoju opartego na bezkresnym wzroście należy zastąpić kulturą równowagi i rozwoju jakościowego" (Wieloryb też... 2009, s. 30). Taki rozwój jest możliwy dzięki uświadomieniu ludziom, że ich indywidualne zachowania, zakupy, inwestycje, wybory polityczne itp. dotyczą nie tylko ich osobiście, ale szerokiego otoczenia, a także przyszłych pokoleń.

Nie wchodząc $w$ spory definicyjne można zauważyć, że świadomość ekologiczna jest:

- zjawiskiem subiektywnym i powinna być oceniana z punktu widzenia jednostek;

- procesem złożonym, który przebiega w zależności od stopnia społecznej akceptacji idei i norm moralnych oraz pogłębiania wiedzy o ekologicznych skutkach form gospodarowania i postępowania wobec środowiska.

Należy zaznaczyć, że normy moralne są wynikiem tradycyjnego stosunku ludzi do środowiska, natomiast wiedza - efektem edukacji i bezpośrednich obserwacji. Dlatego można się zgodzić z poglądami dotyczącymi konieczności edukacji wszystkich podmiotów eksploatujących środowisko.

Badając wpływ mody można zaproponować następujący podział uwarunkowań na działania proekologiczne potencjalnych turystów:

1. Uwarunkowania osobiste - wynikają z troski o własne zdrowie, jakość i bezpieczeństwo wypoczynku.

2. Uwarunkowania społeczne (konformistyczne) - są skutkiem zgody na procesy i zjawiska, jakie dzieją się we współczesnym społeczeństwie: mody na ekologię, obowiązkowych przepisów itp.

3. Uwarunkowania świadomościowe (ideologiczne) - wynikają ze zrozumienia procesów degradacji środowiska, z chęci zapobiegania tym procesom i głębokiej troski o przyszłość.

Ad 1. Czynniki o charakterze osobistym wpływające na proekologiczne zachowania $\mathrm{w}$ procesie decyzyjnym związane są z ogólnymi zmianami modelu konsumpcji. Zauważa się bowiem trend do podkreślania takich wartości, jak: zdrowie, młodość, dobry wygląd i forma fizyczna. Realizowaniu tych wartości służy poszukiwanie towarów zdrowych, bezpiecznych i naturalnych. Zachowania konsumentów o charakterze proekologicznym wy- 
nikające z dążeń osobistych są konsekwencją układu potrzeb zgodnych z modelem A. Maslowa. Potrzeby fizjologiczne i bezpieczeństwa decydować moga że turysta wybierze wypoczynek w czystym otoczeniu, będzie konsumował bezpieczne dla zdrowia produkty. Taki konsument może poszukiwać hotelu wykonanego $\mathrm{z}$ bezpiecznych, nieszkodliwych materiałów, może chcieć nabywać sprawdzona, czystą żywność i wodę. Dlatego producenci i usługodawcy powinny informować o proekologicznych rozwiązaniach, których poszukiwać będzie turysta. Rosnący poziom świadomości ekologicznej społeczeństwa oraz zainteresowanie tą problematyką powoduje, że konsumenci chcą otrzymywać informacje coraz bardziej precyzyjne i wiarygodne. Dla osoby, której ekologiczne decyzje nabywcze wynikają z uwarunkowań osobistych ważne jest poczucie, że w otoczeniu nie znajdują się przedmioty wpływające ujemnie na zdrowie (zakłady przemysłowe, urządzenia domowe, kuchenne itp.). Potrzeby znajdujące się na wyższym poziomie $\mathrm{w}$ piramidzie Maslowa również mogą być związane z uwarunkowaniami o charakterze ekologicznym, które wynikają jedynie z pobudek osobistych. Do grupy potrzeb szacunku i uznania mogą należeć potrzeby bycia ważnym i szanowanym poprzez pełnienie funkcji $\mathrm{w}$ organizacjach związanych $z$ ochroną środowiska, a do grupy potrzeb samorealizacji można zaliczyć chęć rozwoju duchowego poprzez kontemplację przyrody $w$ nieskażonym otoczeniu.

Sama świadomość znaczenia środowiska dla zdrowia i jakości życia nie jest tożsama z ochroną przyrody, jednak stanowić może punkt wyjścia do głębszego zainteresowania i poszerzania wiedzy, co w rezultacie przekładać się może na rzeczywiste działania proekologiczne. Świadomość ekologiczna konsumentów, w tym turystów, może wpływać na:

- codzienne, rutynowe czynności wykonywane w domu lub w pracy;

- zakup dóbr i usług;

- sposoby spędzania czasu wolnego;

- wybór miejsca i formy wypoczynku lub podróży.

Ad 2. Na decyzje nabywcze potencjalnego turysty, które są zgodne $\mathrm{z}$ modelem proekologicznym, mogą wpływać uwarunkowania związane z naciskiem społeczeństwa, grup odniesienia, liderów opinii publicznej, a także (a może przede wszystkim) producentów i usługodawców. Potencjalny konsument ulega ich wpływowi, co czasem wynikać może nie tyle z własnych przekonań, co z chęci dostosowania się do społeczeństwa, w którym funkcjonuje. Dlatego w niniejszym artykule uwarunkowania te nazwano społecznymi bądź konformistycznymi. Tego typu zachowania odpowiadają pewnej krótkotrwałej modzie na produkty ekologiczne. Odnosząc ten typ zachowania do wspomnianej piramidy potrzeb A. Maslowa, 
można jako przykład uznać grupę potrzeb społecznych, do której należy potrzeba poczucia przynależności do organizacji lub grupy społecznej zajmującej się ochroną środowiska. Ta grupa potrzeb będzie też warunkować np. wybór wypoczynku w „ekohotelu”, jeśli pojedzie tam szef, ceniona osoba, a pracownik dokonuje tego wyboru motywowany chęcią naśladownictwa, a nie chęcią ochrony środowiska. Takie motywacje mogą również wynikać z potrzeb szacunku i uznania, jeśli turysta wybiera zachowania proekologiczne, jeśli chce być uznawany za osobę szanującą środowisko lub pragnie przynależeć do grupy społecznej, w której modny i oceniany jako pozytywny jest ekologiczny sposób konsumpcji, w tym wypoczynku.

Ad 3. Ostatnia z grup uwarunkowań proekologicznych zachowań nabywczych w zaproponowanym powyżej podziale obejmuje uwarunkowania wynikające ze zrozumienia procesów degradacji środowiska, z chęci zapobiegania tym procesom i głębokiej troski o przyszłość. Można je uznać za najpełniej odpowiadające wzrostowi świadomości ekologicznej, dlatego nazwano je uwarunkowaniami świadomościowymi (ideologicznymi).

Turysta podejmuje decyzje ze względu na własne potrzeby, ale może być motywowany chęcią własnego wpływu na ochronę środowiska. Tym bardziej, że "powrót do natury i ochrona środowiska" wyodrębniane są jako zauważalne style czy sposoby życia charakterystyczne dla końca XX w. Po osiągnięciu odpowiednio wysokiego poziomu rozwoju jakość życia w większym stopniu zależy od kultury, relacji z innymi, rodziny, przyjaciół niż od nieustannego zwiększania konsumpcji (Wieloryb też... 2009, s. 30). Dlatego podnoszenie poziomu rozwoju społeczeństwa powoduje, że coraz więcej osób może być zainteresowanych nie tylko poprawą własnych warunków życia, ale ochroną środowiska i dbałością o przyszłość Ziemi. Znajduje to odzwierciedlenie w modelu trwałej konsumpcji, który wynika $\mathrm{z}$ uświadomienia faktu, że kontynuacja prostej liniowej zależności liczby ludności i procesów konsumpcji prowadzi do nadmiernej eksploatacji środowiska naturalnego. Konsumenci uświadamiają sobie związek własnych zachowań z innymi sferami życia społeczno-gospodarczego. Zauważaja że ich decyzje nabywcze mogą kształtować środowisko, w którym żyja a zatem mogą również wpływać na jakość życia nie tylko własnego, ale całego społeczeństwa.

W tym przypadku wpływ mody jest długofalowy i raczej na całokształt zachowania oraz na cały system zakupów odzwierciedlony w modelu konsumpcji, niż na sporadyczny zakup modnych produktów poprzedzonych przedrostkiem „eko".

Moda na produkty, które zawierają w swej nazwie przedrostek „eko” doprowadziła do powszechnego nadużywania tego typu nazw i błędnego 
rozumienia pojęcia „świadomość ekologiczna”. Wielu konsumentów i producentów uważa, że przejawem tej świadomości jest nabywanie „ekoproduktów”. W Polsce większość firm umieszcza przedrostek „eko” na własną rękę (BOHDANOWICZ 2008, s. 67). Ma to służyć zachęceniu do kupna wszystkich konsumentów podążających za "modą na ekologię". Aby zachowania konsumentów usług turystycznych nie były tylko efektem takiej krótkotrwałej mody działania proekologiczne turystów, powinny wynikać z autentycznej świadomości ekologicznej. Co więcej, turyści, którzy w swoich wyborach nabywczych uwzględniają uwarunkowania ekologiczne, muszą być świadomi, że te wybory nie zawsze są zgodne $z$ innymi celami i wartościami, np.:

- pobyt w ekohotelu, korzystanie z lokalnych usług i wyrobów lokalnych producentów może wiązać się z wyższymi kosztami niż wybór usług i produktów "masowych";

- $\quad$ wybór produktów ekologicznych może wiązać się z mniejszą wartością użytkową (np. dojazd do miejsca wypoczynku publicznym środkiem transportu może być bardziej uciążliwy niż dojazd własnym samochodem);

- produkty i usługi ekologiczne mogą charakteryzować się niższą estetyką niż inne produkty (np. w ekohotelu łazienki mogą być skromniej urządzone niż w innych obiektach);

- zachowania proekologiczne mogą być sprzeczne z ogólnie przyjętym systemem wartości nastawionym na demonstracyjną konsumpcję (podróżując publicznymi środkami transportu, nie kupując nadmiernej ilości dóbr, wybierając lokalne produkty turysta może być postrzegany przez innych jako osoba, której nie stać finansowo na „lepsze wakacje").

Aby nie poddać się wymienionym dylematom, turysta wybierający zachowania proekologiczne musi być osobiście przekonany do słuszności swoich decyzji. Często ograniczeniem jest postrzeganie własnych działań jako marginalnych, drobnych, które nie mają wpływu na społeczeństwo, gospodarowanie zasobami i całą planetę.

W tym miejscu można przypuszczać, że o faktycznych działaniach proekologicznych w turystyce decydować będą procesy charakterystyczne dla rozprzestrzeniania mody obejmujące nie tylko proces podejmowania decyzji nabywczych, ale szeroko rozumiane zachowania konsumenckie. Te zachowania obejmuja cały proces, od zbierania informacji o produktach, przez zachowania $\mathrm{w}$ czasie konsumpcji, aż do zachowań pozakupowych wyrażających się $\mathrm{w}$ poleceniu produktu znajomym. Wtedy turysta będzie nie tylko nabywał modne, ekologiczne wakacje, ale starał się z pełną świa- 
domościa aby jego pobyt w miejscu wakacji nie przyczyniał się do degradacji środowiska przyrodniczego.

\section{Podsumowanie}

Moda jest ważnym uwarunkowaniem podejmowania aktywności turystycznej. Wpływa na decyzje konsumentów (turystów) dotyczące samego podjęcia podróży turystycznej, ale również na decyzje, co do formy tej podróży oraz zestawu dóbr i usług, z których turysta korzysta w miejscu pobytu.

Poprzez efekt naśladownictwa moda wywiera wpływ na postawy ludzi. Takimi postawami moga być zachowania proekologiczne $\mathrm{w}$ czasie podróży. Zachowania te są następstwem świadomości ekologicznej, która uwarunkowana jest czynnikami o charakterze osobistym, społecznym oraz świadomościowym. Postępowanie turysty motywowanego czynnikami świadomościowymi najpełniej odpowiada wysokiemu poziomowi świadomości ekologicznej, ponieważ wynika z autentycznej troski o środowisko. Konsument motywowany tą troską chce być odpowiedzialny za otaczającą go przyrodę, a nie jedynie ulega modzie na produkty ekologiczne.

W efekcie tych procesów pojawia się nowy konsument skłonny do kupna ekologicznych towarów i usług, do zmiany swojego stylu życia, przyzwyczajeń i modelu konsumpcji, aby chronić środowisko. Taki turysta dba o segregację śmieci, oszczędza energię i wodę, nabywa produkty regionalne, chodzi po wyznaczonych szlakach. Mając na uwadze negatywne skutki zatłoczenia, wybiera środki transportu publicznego zostawiając samochód na parkingu. Autentyczna postawa proekologiczna przejawia się w tym, że w miejscu wakacji turysta zachowuje się tak samo oszczędnie jak w miejscu zamieszkania (NIEZGODA 2010b). Szczególnie dotyczy to oszczędzania zużycia wody i energii, co w mieszkaniu turysty przekłada się na realne oszczędności finansowe, natomiast w czasie pobytu w hotelu zależy tylko od samego turysty. Turysta o wysokim stopniu świadomości ekologicznej powinien zachęcać do zachowań proekologicznych, a także sygnalizować podmiotom świadczącym usługi turystyczne potrzebę kształtowania oferty zgodnej z wymaganiami ochrony środowiska. 


\section{BIBLIOGRAFIA}

BOHDANOWICZ P., 2008, Turystyka a świadomość ekologiczna, Wyd. Adam Marszałek, Toruń.

FOURNIER S., 1998, Consumers and Their Brands. Developing Relationship Theory in Consumer Research, "Journal of Consumer Research", 24, s. 343-373.

KÖNIG R., 1979, Potęga i urok mody, Wydawnictwa Artystyczne i Filmowe, Warszawa.

NiezGODA A., 2010a, Nowe trendy w popycie - wyzwanie dla obszarów recepcji turystycznej, [w:] Nauka i dydaktyka w turystyce i rekreacji, S. Tanaś (red.), Łódzkie Towarzystwo Naukowe, Łódź, s. 21-34.

NiezGODA A., 2010b, Rola świadomości ekologicznej w ksztattowaniu konkurencyjnego produktu turystycznego, [w:] Konkurencyjność miast i regionów na globalnym rynku turystycznym, J. Sala (red.), PWE, Warszawa, s. 197-217.

RUDNICKI L., 2010, Zachowania konsumentów na rynku turystycznym, Wyd. Proksenia, Kraków.

SEATON A. V., 2002, Tourism as Metenpsychosis and Metensomatosis, [w:] The tourist as a metaphor in social world, CAB International Wallingford, s. 135-168.

SiLlaMy N., 1994, Stownik psychologii, Wyd. Książnica, Warszawa.

Stownik języka polskiego 1978, M. Szymczak (red.), PWN, Warszawa.

Wieloryb też człowiek, rozmowa z Rexem Weylerem, współzałożycielem organizacji Greenpeace, 2009, „Polityka”, 50, s. 30. 